\title{
The Results Obtained on Production of Alfalfa on Sandy Soils of Field Dabuleni by Administration of Loess and Chemical Fertilizers
}

\author{
ANCA-LUIZA STANILA ${ }^{1 *}$, IULIAN RATOI ${ }^{2}$, AURELIA DIACONU ${ }^{2}$, CATALIN CRISTIAN SIMOTA ${ }^{1}$ \\ ${ }^{1}$ National Research Institute for Soil Science, Agrochemistry and Environment-ICPA, Bucharest, 61 Marasti Blvd., \\ 011464, Bucharest, Romania \\ ${ }^{2}$ Research and Development Centre for Plant Growing on Sands Dabuleni, 130 Victoria Str., 207220, Dolj, Romania
}

\begin{abstract}
Recovery sandy soils top was a major concern, sandy soil cultivation with the crop plants had the main goal need to increase the agricultural production. Sands in southern Oltenia offers less favorable conditions of plant life, which is why the range of cultivated plants is much lower than in other areas. Seed plants that require small and early seed (alfalfa) are affected by the negative effect of the wind, which blows away the sand particles, lesion rooted young plants or compromising their culture. On sandy soils in southern Oltenia (Field Dabuleni), forage crops help to improve physical, hydro-chemical properties, change the living conditions for plants, animals and humans, create an ecological balance that preserves the environment, partly destroyed by abolishing plantations of Robinia pseudocacia and leveling dunes relief for arranging irrigation.Among perennial leguminous pure culture, alfalfa is the most valuable forage plant feed all animal species, both for its output, especially for forage quality. Achieving quality parameters alfalfa is conditional, namely the establishment of the following technologies, namely: mowing standing of the optimal phenological stages of the plant, the establishment range of mowing or the number of harvest in a year.
\end{abstract}

Keywords: alfalfa, Field Dabuleni, sandy soils, loess, chemical fertilizers, production

Recovery sandy soils southern Oltenia include a system specifically, the rationally and integrated with less demanding plants to soil fertility and tolerance to stress factors, to ensure profitability and the environment $[1,2]$.

Use crop production in sandy soils in Southern Oltenia (Field Dabuleni) is greatly influenced by the properties of these soils, due to their sandy texture (more than $85-90 \%$ sand, coarse sand frequently than quartz). They have a high capacity for air, a low water retention capacity. The content low clay and humus these soils causes and poverty in nutrients $[3,4]$.

In the sandy soils of as a result of work shaping - levelling made during irrigation system planning Sadova-Corabia.

For the sandy soils, the competition between plants for solar energy, water and nutrients available to plants is of great significance, these soils because the space on the back of each plant must provide water and nutrients for plant growth and development sufficient [5-11].

Research undertaken in period 2017-2018 to for culture of alfalfa within Research and Development Centre for Plant Growing on Sands Dabuleni, they were to improve physical, hydro and chemical properties of sandy soils by administration of loess or chemical fertilizers used in different stages of vegetation and production obtained.

Alfalfa (Medicago sativa) can be used in animal feed as a pale green fodder mass in the form of hay, semisiloz or dried and ground, or converted into flour or granules.

As a mature plant, alfalfa resistant to low temperatures, which can reach up to $-40{ }^{\circ} \mathrm{C}$, the atmosphere.

When the young plants resistance is reduced to $-5^{\circ} \mathrm{C}$.

Alfalfa (Medicago sativa) are important and some of the biological characteristics, such as: drought resistance, sufficient positive reaction to the water supply and nutrients, high energy regeneration.

Also, alfalfa presents importance and that ameliorative plant of sandy soils, you rich in nitrogen through symbiosis bacteria Rhizobium meliloti, leaving the ground clear of weeds, well structured and rich in nutrients, in particular nitrogen and calcium.

\section{Experimental part}

Material and method

Research culture alfalfa were carried out under irrigation conditions, on sandy soils (eutric psamosol) shaping levelling. Experience has been placed in the field, in randomized blocks in five variants, including the control, with four repetitions, surface experimental plot is $90 \mathrm{~m}^{2}(12 \mathrm{~m} \times 7.5 \mathrm{~m})$ [12].

Before placing experience in field they were given loess rates and chemical fertilizers - ammonium nitrate $(33.5 \%$ N) and complex NPK - 16-16-16 on the surface, namely:

*email: luizastanila2011@yahoo.com

Loess doses: 
$\mathrm{V}_{1}$ - no added loess

$\mathrm{V}_{2}-40 \mathrm{t} / \mathrm{ha}$

$\mathrm{V}_{3}-80 \mathrm{t} / \mathrm{ha}$

$\mathrm{V}_{4}-120 \mathrm{t} / \mathrm{ha}$

$\mathrm{V}_{5}-160 \mathrm{t} / \mathrm{ha}$

Complex fertilizer NPK doses of the type: 16-16-16:

$\mathrm{R}_{1}$ - no fertilizer

$\mathrm{R}_{2}$ - N50 (25 before sowing +25 to flowering) P40 (20 before sowing +20 to flowering ) K40 (20 before sowing +20 to flowering)

$\mathrm{R}_{3}-\mathrm{N} 100$ (50 before sowing +25 to flowering +25 after flowering) P 80 (40 before sowing +40 to flowering) $\mathrm{K}$ 80 ( 40 before sowing +40 to flowering)

$\mathrm{R}_{4}-\mathrm{N} 150$ (75 before sowing $+37,5$ to flowering $+37,5$ after flowering) P120 ( 60 before sowing +60 to flowering) K 120 (60 before sowing +60 after flowering)

The establishment culture of alfalfa was performed according to the method specified in sandy soils, the ground work is carried out as follows: plowing, discing, rolling before sowing and after sowing, sowing at a depth of $1.5-2 \mathrm{~cm}$ and application of irrigation water to $250 \mathrm{~m}^{3} / \mathrm{ha}$.

Determined uniformity sunrise, the number of emerged plants $/ \mathrm{m}^{2}$. During the vegetation they were made cultivation and weeds control.

Production of alfalfa was brought to $9 \%$ humidity, and interpretation of research results was done by variance analysis method.

Production is shown in the form of green mass in $\mathrm{kg} / \mathrm{ha}$ reported the area occupied by alfalfa.

Interpretation of the results has been submitted in accordance with "Methodology developing soil studies", ICPA Bucharest, 1987 [13] provided for in current legislation on the subject.

\section{Results and discussions}

Experience the culture of alfalfa (Medicago sativa) it was placed on the terrace III of the Danube, on a sand and sandy soils (eutric psamosol) under irrigation and fight against the wind deflation to Research and Development Centre for Plant Growing on Sands Dabuleni, County Dolj.

Areas with sandy soils not intervened by anthropic by shaping-leveling works appear relief dunes and interdune. The dunes are longitudinal dominant wind direction width of $200 \mathrm{~m}$ and the height of often reaching 15-20 m.

Dune-interdune amplitude varies greatly, from $1.5 \mathrm{~m}$ to $20 \mathrm{~m}$, which is determined by the presence between the main dunes of a large number of less-developed dunes, whose height does not exceed 1-2 m (Figure 1).

The climatic conditions in recent years have been very unsuitable for most crops feed, water stress and heat due to a drastic enough, during critical vegetation. In july the average monthly temperature was $24.8^{\circ} \mathrm{C}$ with $1.5^{\circ} \mathrm{C}$ higher than the annual average. Maxima july was $40.8{ }^{\circ} \mathrm{C}$.

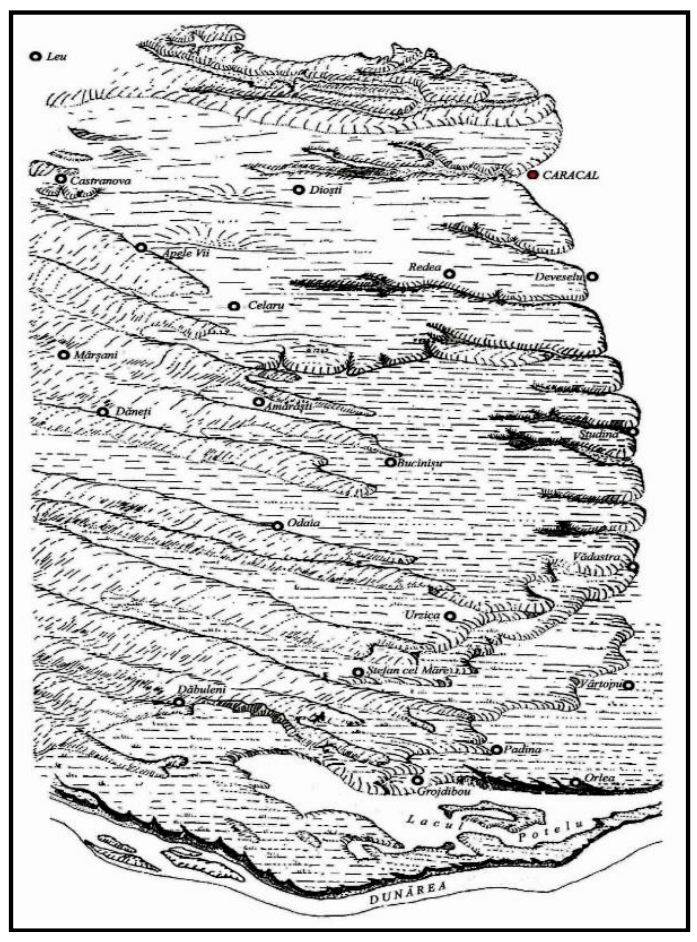

Fig. 1. Relief dunes and interdune in the Romanati Plain [14]. 
The greatest amount of precipitation fell in july $(120.8 \mathrm{~mm})$ compared to the period from august to september where rainfall was lower (18.2 to $28.2 \mathrm{~mm}$ ) (Table 1$)$.

Table 1

CLIMATIC CONDITIONS DURING MAY-SEPTEMBER 2017 RECORDED AT THE STATION TO CCDCPN DABULENI

\begin{tabular}{|c|c|c|c|c|c|}
\hline Month/ decade & May & June & July & August & September \\
\hline $\begin{array}{c}\text { Nr. days with } \\
\text { maximum } \\
\text { temperatures of } 25- \\
30{ }^{\circ} \mathrm{C}\end{array}$ & 12 & 8 & 6 & 4 & 6 \\
\hline $\begin{array}{c}\text { Nr. days with } \\
\text { maximum } \\
\text { temperatures } \\
\text { between } \\
30-35^{\circ} \mathrm{C} \\
\end{array}$ & 1 & 13 & 16 & 15 & 12 \\
\hline $\begin{array}{c}\text { Nr. days with } \\
\text { maximum } \\
\text { temperatures above } \\
35^{\circ} \mathrm{C} \\
\end{array}$ & 0 & 8 & 6 & 10 & 4 \\
\hline $\begin{array}{l}\text { The monthly average } \\
\left({ }^{\circ} \mathrm{C}\right)\end{array}$ & 17.8 & 24.0 & 24.8 & 24.8 & 21.7 \\
\hline $\begin{array}{c}\text { Monthly minimum } \\
\left({ }^{\circ} \mathrm{C}\right)\end{array}$ & 4.7 & 12.9 & 13.3 & 11.0 & 6.7 \\
\hline $\begin{array}{c}\text { Monthly maximum } \\
\left({ }^{0} \mathrm{C}\right)\end{array}$ & 31.4 & 41.2 & 40.8 & 40.4 & 36.9 \\
\hline Precipitation $(\mathrm{mm})$ & 78.6 & 17.4 & 120.8 & 28.8 & 18.2 \\
\hline $\begin{array}{l}\text { The average yearly } \\
\text { temperature (1956 - } \\
\text { 2017) }\end{array}$ & 17.4 & 21.4 & 23.2 & 22.6 & 17.8 \\
\hline
\end{tabular}

Vegetation territory studied it consists of psammophyte adapted to drought conditions, among them: Mollugo cerviana, Draba verna, Veronica arvensis, Digitaria sanguinalis, Amaranthus retroflexus, Portulaca oleracea, Centaurea arenaria, Potentila arenaria, Tragus racemosus, Salsola ruthenica (Figure 2).

Groundwater is between 2-3 m depth, compared with 5 to $10 \mathrm{~m}$ depth, the situation before planning irrigation works.

From the observations, it appears that the groundwater is based on the formation loess and it appears as free water in the soil profile [15-17].

In terms of taxonomic, soil in the building experience it belongs to the class protisols, namely a eutric psamosol under irrigation conditions $[18,19]$.

\section{Morphological characteristics}

Eutric psamosol is characterized by a profile of Aop-Ao-AC- $C_{1}-C_{2}-C_{3}-C_{4}$ moderately developed (Figure 3).

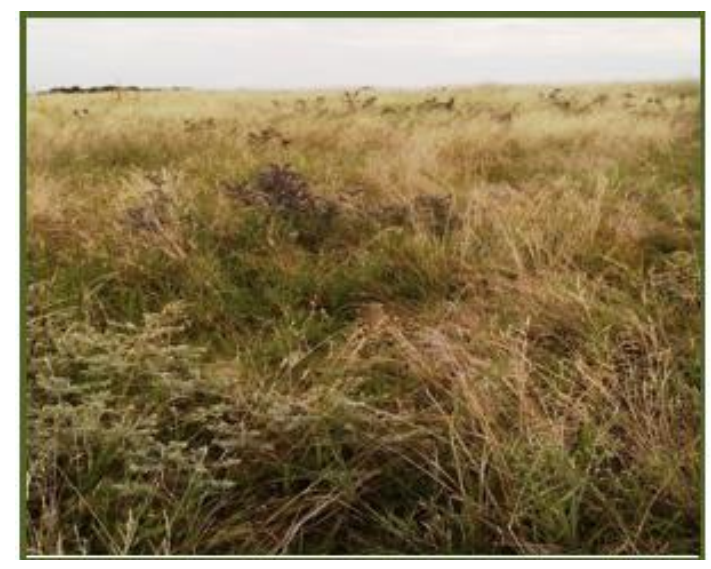

Fig. 2. Psammophyte on terrace III Danube in Field Dabuleni

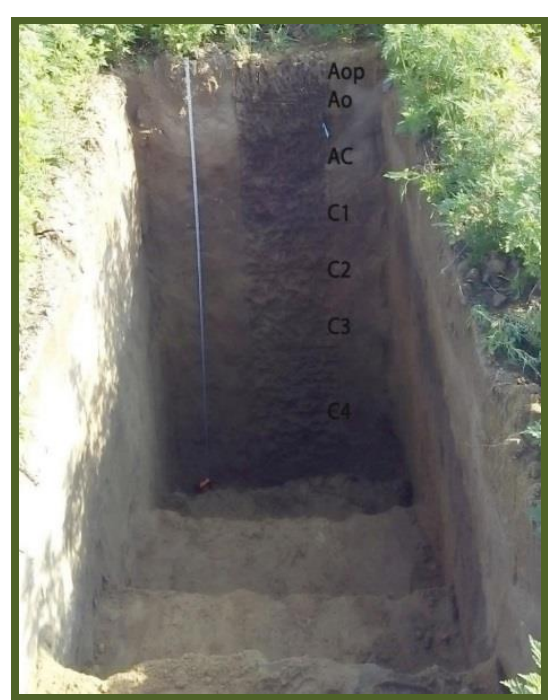

Fig. 3. Location of the soil profile (eutric psamosol) in the experimental Field Dabuleni 
Aop - 0-20 cm; coarse sand, dark brown color (10YR4/3) in the wet state and brown (10YR 5/3) in the dry state, massive structure, moderately loose, friable wet, common grass roots fine, gradual transition;

Ao - 21-35 cm; coarse sand, dark brown - brown (10YR 4/3-5/3) to wet and yellowish brown (10YR 5/4) in the dry state, unstructured, loose, friable wet, grass roots fine common gradual transition;

$\boldsymbol{A C}$ - 36-52 cm; coarse sand, dark yellowish brown (10YR 4/4) wet and yellowish brown (10YR 5/6) in the dry state, unstructured, friable wet, non-adhesive, non-plastics, grass roots fine rare, smooth transition;

$\boldsymbol{C}_{\boldsymbol{I}}$ - 53-95 cm; coarse sand, brown (10YR 5/3) wet and pale brown (10YR 6/3) in the dry state, unstructured, nonplastics, non-adhesive, thin roots rare, gradual transition;

$\boldsymbol{C}_{2}-96-132 \mathrm{~cm}$; coarse sand, yellowish brown (10YR 5/6) wet and brown yellow (10YR 6/6) in the dry state, unstructured, non-plastics, not effervescent, gradual transition;

$\boldsymbol{C}_{3}$ - 133-170 cm; coarse sand, yellowish brown (10YR 6/4) wet and very pale brown (10YR 7/3) in dry, nonstructured, light plastic, thin adhesive, does effervescence, gradual transition;

$\boldsymbol{C}_{\boldsymbol{4}}-171-200 \mathrm{~cm}$; coarse sand, yellow brown (10YR 6/6) wet and yellow (10YR 7/6) in the dry state, unstructured, weak plastic, weak adhesive, does not effervesce.

Eutric psamosol is characterized by a coarse texture, in which content coarse sand can reach up to $76 \%$ and the clay up to a maximum of $1.1 \%$.

The chemical reaction of these soils are grouped within the range between 5.65 to 6.45 horizons Ao and AC, the weak-moderate acid and at the horizon $\mathrm{C}_{4}$ is neutral $(\mathrm{pH}=7.0)$. In terms of content of humus, eutric psamosol are generally low in humus, containing from 0.35 to $1.06 \%$ [20].

For weed control in alfalfa applied herbicide Pulsar 40 in a dose of 1.0-1.2 1 /ha, in phase 2-4 leaves of annual dicotyledonous, that 1-3 leaves to twinning for annual monocotyledonous.

Harvesting alfalfa is a work of great importance because it directly affects the production and the nutritional value of the feed.

The stage of plant development is the morphological index determines the optimum time harvesting the culture alfalfa (Figure 4).

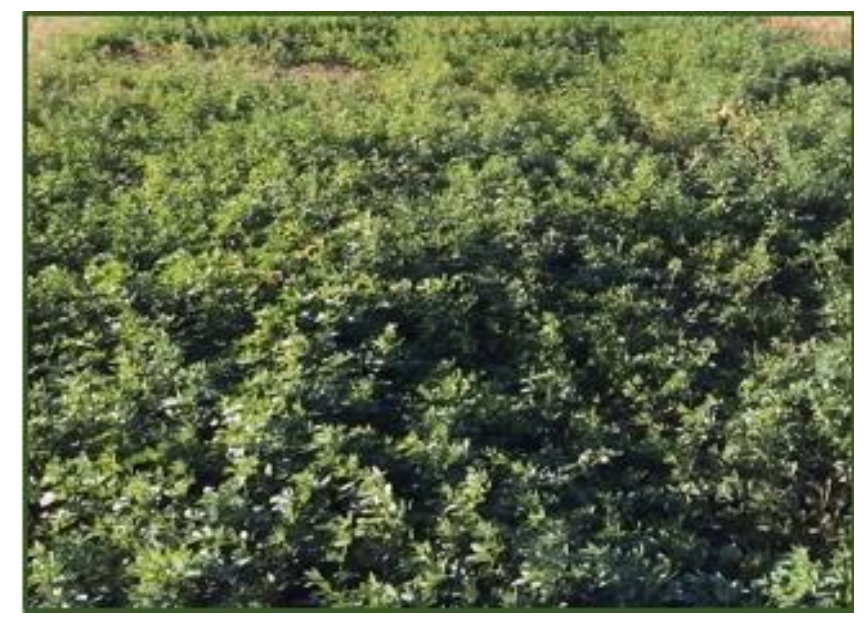

Fig. 4. Culture of alfalfa in the experimental Field Dabuleni

As a result, during the harvesting period between phenophases the bud and early flowering it was the optimum time for cutting of alfalfa plants.

\section{Conclusions}

During the experiment they were achieved four sewing at intervals of 40-45 days (Table 2, 3, 4, 5). After harvesting, alfalfa leave the field $1-1 \frac{1}{2}$ day, to reach $35-40 \%$ moisture.

Table 2

PRODUCTION OF ALFALFA (Kg/HA) IN THE YEAR 2018 SEWING I - CCDCPN DABULENI

\begin{tabular}{|c|c|c|c|c|c|}
\hline $\begin{array}{c}\text { Variants/ } \\
\text { Repetitions }\end{array}$ & $\mathbf{V}_{\mathbf{1}}$ & $\mathbf{V}_{\mathbf{2}}$ & $\mathbf{V}_{\mathbf{3}}$ & $\mathbf{V}_{\mathbf{4}}$ & $\mathbf{V}_{\mathbf{5}}$ \\
\hline $\mathbf{R}_{\mathbf{4}}$ & 0.68 & 0.65 & 0.55 & 0.57 & 0.77 \\
\hline $\mathbf{R}_{\mathbf{3}}$ & 1.29 & 0.89 & 0.86 & 0.77 & 0.91 \\
\hline $\mathbf{R}_{\mathbf{2}}$ & 0.94 & 0.87 & 1.15 & 1.30 & 1.35 \\
\hline $\mathbf{R}_{\mathbf{1}}$ & 0.85 & 0.65 & 0.89 & 0.85 & 1.10 \\
\hline
\end{tabular}


Table 3

PRODUCTION OF ALFALFA (Kg/HA) IN THE YEAR 2018 SEWING II - CCDCPN DABULENI

\begin{tabular}{|c|c|c|c|c|c|}
\hline Variants/Repetitions & $\mathbf{V}_{\mathbf{1}}$ & $\mathbf{V}_{\mathbf{2}}$ & $\mathbf{V}_{\mathbf{3}}$ & $\mathbf{V}_{\mathbf{4}}$ & $\mathbf{V}_{\mathbf{5}}$ \\
\hline $\mathbf{R}_{\mathbf{4}}$ & 0.72 & 1.07 & 1.12 & 0.94 & 0.84 \\
\hline $\mathbf{R}_{\mathbf{3}}$ & 1.42 & 1.16 & 0.79 & 1.26 & 1.06 \\
\hline $\mathbf{R}_{\mathbf{2}}$ & 1.18 & 1.13 & 1.30 & 1.46 & 1.34 \\
\hline $\mathbf{R}_{\mathbf{1}}$ & 1.85 & 1.30 & 1.60 & 1.47 & 0.75 \\
\hline
\end{tabular}

Table 4

PRODUCTION OF ALFALFA (Kg/HA) IN THE YEAR 2018 SEWING III - CCDCPN DABULENI

\begin{tabular}{|c|c|c|c|c|c|}
\hline Variants/Repetitions & $\mathbf{V}_{\mathbf{1}}$ & $\mathbf{\mathbf { V } _ { \mathbf { 2 } }}$ & $\mathbf{\mathbf { V } _ { \mathbf { 3 } }}$ & $\mathbf{V}_{\mathbf{4}}$ & $\mathbf{V}_{\mathbf{5}}$ \\
\hline $\mathbf{R}_{\mathbf{4}}$ & 1.18 & 1.31 & 1.21 & 1.04 & 1.05 \\
\hline $\mathbf{R}_{\mathbf{3}}$ & 1.52 & 1.62 & 1.66 & 1.36 & 1.16 \\
\hline $\mathbf{R}_{\mathbf{2}}$ & 1.41 & 1.22 & 1.40 & 1.53 & \\
\hline $\mathbf{R}_{\mathbf{1}}$ & 1.51 & 1.28 & 1.35 & \multicolumn{2}{c|}{0.34} \\
\hline
\end{tabular}

Table 5

PRODUCTION OF ALFALFA (Kg/HA) IN THE YEAR 2018 SEWING IV - CCDCPN DABULENI

\begin{tabular}{|c|c|c|c|c|c|}
\hline Variants/Repetitions & $\mathbf{V}_{\mathbf{1}}$ & $\mathbf{V}_{\mathbf{2}}$ & $\mathbf{\mathbf { V } _ { \mathbf { 3 } }}$ & $\mathbf{V}_{\mathbf{4}}$ & 0.62 \\
\hline $\mathbf{R}_{\mathbf{4}}$ & 0.75 & 0.61 & 0.86 & 0.65 \\
\hline $\mathbf{R}_{\mathbf{3}}$ & 1.04 & 1.11 & 0.76 & 0.03 & 0.86 \\
\hline $\mathbf{R}_{\mathbf{2}}$ & 0.67 & 0.87 & 1.20 & 0.85 & 0.88 \\
\hline $\mathbf{R}_{\mathbf{1}}$ & 1.05 & 0.73 & 0.84 & 0.94 & 0.87 \\
\hline
\end{tabular}

Fertilization sandy soils (eutric psamosol) in the experimental field sewing III with $80 \mathrm{t} / \mathrm{ha}$ loess and chemical fertilizers N100 ( 50 before sowing +25 to flowering +25 after flowering), P 80 ( 40 before sowing +40 to flowering) and $\mathrm{K} 80$ (40 before sowing +40 to flowering) it proved effective with alfalfa production of $1.66 \mathrm{~kg} / \mathrm{ha}$.

When the sandy soils (eutric psamosol) sewing IV were fertilized with 80 t/ha loess and N50 (25 before sowing + 25 to flowering), P40 (20 before sowing +20 to flowering ) and K40 (20 before sowing +20 to flowering), alfalfa production was low $-1.20 \mathrm{~kg} / \mathrm{ha}$.

Acknowledgement: We are very thankful to Research and Development Centre for Plant Growing on Sands Dabuleni for providing the necessary facilities to carry out this work.

\section{References}

1. COTET, P., Romanian Plain, Integrated geomorphology study, Publisher Ceres, Bucharest, 1976.

2. HALALAU, D., PARICHI, M., MACARAU, ST., BANITA, EMILIA, Fodder crops on sands and sandy soils of R.S Romania, Publisher Ceres, Bucharest, 1985, p. 167.

3. PARICHI, M., STANILA, ANCA-LUIZA, CRUCERU, N., Soils main relief units in Romania, Romania for Tomorrow Publishing House, Bucharest, 2006, 179 p.

4. PARICHI, M., STANILA, ANCA-LUIZA, ISPAS, ST., Changes in the pedolandscape of the Romanati Plain (The Field of Dabuleni), Scientific Papers UASVM Bucharest, Series A, Agronomy, Vol. LV, 2012, p. 87-90.

5. OANCEA, C., PARICHI, M., Soils Oltenia Plain of East, Technical and economic studies, Institute of Geology, Series C, Bucharest, 1970.

6. OANCEA, C., PARICHI, M., Studies and research on knowledge of soils in Sadova-Corabia irrigation system, Annals Research Institute of Soil Science and Agrochemistry, Vol. XXXIX, Bucharest, 1982, p. 527-552.

7. OPREA, C.V., CRISAN, I., DRAGAN, I., OPRIS, L., POPESCU, G., Contributions to the knowledge and enhancement of the sands in the north-west Romania, Studies and Biological Research, IV/1-2, Timisoara, 1957.

8. PARICHI, M., TRANDAFIRESCU, T., DANILIUC, D., Sandy soils in Romania, Bul. Inf. ASAS, No. 12, Bucharest, 1978.

9. PARICHI, M., COZOS, G., Opportunity sandy land leveling in terms of efficient agriculture, Soil science, No. 1, Bucharest, 1992, p. 12-20.

10. PARICHI, M., STAICU, FILUTA, BANITA, P., Sandy soils of the Romanian Plain, Publications SNRSS, Vol. 29 D, Bucharest, 1997.

11. PARICHI, M., STANILA, ANCA-LUIZA, PLOAE, P., Integrated research on the evolution of territories with landscaped sandy soils, Archive ICPA, Bucharest, 1998.

12. STANILA, ANCA-LUIZA, PARICHI, M., Soil mapping, Romania for Tomorrow Publishing House, Bucharest, 2001,160 p.

13. ***, Methodology development of soil studies (3 Volume), ICPA, Bucharest, 1987.

14. PARICHI, M., STANILA, ANCA-LUIZA, PLOAE, P., Soils wind landscapes of Romania, Romania for Tomorrow Publishing House, Bucharest, 2013, $146 \mathrm{p}$.

15. STANILA, ANCA-LUIZA, PARICHI, M., Soils Romania, Romania for Tomorrow Publishing House, Bucharest, 2003,192 p.

16. STANILA, ANCA-LUIZA, PARICHI, M., URSARU, P., Pedogeographical observations in the Plain between the Jiu and the Danube, Proceedings, UASVM Bucharest, Series A, Vol. LIII, 2010.

17. STANILA, ANCA-LUIZA, TOTI, M., MUSAT, M., Vulnerability to climatic drought of the soils from the Romanian Plain, Soil Forming Factors and Processes from the Temperate Zone 13, Iasi, 2014, p. 83-89.

18. FLOREA, N., MUNTEANU, I., RUSU, C., DUMITRU, M., IANOS, GH., RADUCU DANIELA, ROGOBETE GH., TARAU, D., Romanian System of Soil Taxonomy (SRTS), Publisher, SITECH, Craiova, 2012, p. 206.

19. ISPAS, ST., STANILA, ANCA-LUIZA, Soils Romania, Publisher Valahia University Press, Targoviste, 2015, p. 246.

20. STANILA, ANCA-LUIZA, SIMOTA, CATALIN CRISTIAN, RATOI, IULIAN, DIACONU, AURELIA, DUMITRU, MIHAIL, Research on improving fertility sandy soils from Dabuleni Field by administration of loess, REV.CHIM.(Bucharest), 70, no. 2, 2019 , p. 543-548.

$\overline{\text { Manuscript received: } 13.03 .2019}$ 
